\title{
DINAMIKA POPULASI $C$. vulgaris DALAM PAPARAN LOGAM BERAT TIMBAL (PB) DENGAN KONSENTRASI YANG BERBEDA SKALA LABORATORIUM
}

\author{
Yonita Ike Putri Dyniari' ${ }^{1}$ Farikhah $^{2}$, Andi Rahmad Rahim ${ }^{2}$ \\ 1. Mahasiswa Prodi Budidaya Perikanan, Fakultas Pertanian Universitas Muhammadiyah Gresik. \\ 2. Dosen Prodi Akuakultur, Fakultas Pertanian Universitas Muhammadiyah Gresik. \\ Email : puputri75@gmail.com ; Phone No.+6282332824801
}

\begin{abstract}
Enhancement of heavy metal concentration in sea water causing poison to sea organism which is happened continously. The purpose of study is to analyze the influence of MTC and the difference of chlorofil-a content toward chlorella sp. Which is added heavy metal $\mathrm{Pb}$ with different concentration in laboratorium scale. Statistical analys that perfomed is Completely Randomized Design (CRD) by four treatments of different $\mathrm{Pb}$ concentration, those are : $5 \mathrm{ppm}$, $10 \mathrm{ppm}, 15 \mathrm{ppm}$ and every treatments acquire 3 repetitions. Parameter that observed are cell amount, daily water quality involving $\mathrm{DO}, \mathrm{Ph}$, temperature, salinity and chlorofil-a content. The data or cell amount that acquire analyzed by using variety (ANOVA), if the result of variety shows the real influence, it is able to be next by using Least Significance Different (LSD) test. The result of this study shows that the explanation of different heavy metal $\mathrm{Pb}$ concentration, signifficanly influenced toward chlorella vulgaris $(\mathrm{P}<0,2)$ cell population. Chlorophyll-a content compared linear with amount of cell population. The parameter estimation of water quality including temperature $30,15-32,24^{\circ} \mathrm{C}, \mathrm{Ph} 8,4-9,0$, Salinity $28,035,8 \%$. DO $5,15-$ $6,06 \mathrm{ppm}$. estimation of water quality towards culture medua during study still worth to used.
\end{abstract}

keywords : $C$. vulgaris, heavy metal ( $P b)$, cell population, chlorophyll-a

\begin{abstract}
ABSTRAK
Peningkatan konsentrasi logam berat air laut menyebabkan racun bagi organisme laut jika berlangsung secara terus menerus. Tujuan penelitian ini untuk menganalisis pengaruh, MTC dan perbedaan kandungan klorofil-a pada populasi Chlorella sp. yang ditambahkan logam berat $\mathrm{Pb}$ dengan konsentrasi yang berbeda dalam skala laboratorium. Analisis statistik yang dilakukan adalah Rancangan Acak Lengkap (RAL) dengan empat perlakuan konsentrasi $\mathrm{Pb}$ yaitu : $5 \mathrm{ppm}, 10 \mathrm{ppm}, 15 \mathrm{ppm}$, setiap perlakuan terdapat 3 ulangan. Parameter yang diamati adalah jumlah sel, kualitas air harian meliputi DO, pH, suhu, salinitas, dan kandungan klorofila. Data jumlah sel yang diperoleh dianalisis menggunakan ragan (ANOVA), apabila hasil ragam menunjukkan pengaruh nyata, dilanjutkan menggunakan uji BNT. Hasil penelitian menunjukkan paparan konsentrasi logam berat timbak $(\mathrm{Pb})$ yang berbeda berpengaruh signifikan terhadap populasi sel $C$. vulgaris $(\mathrm{P}<0,2)$. Kandungan klorofil-a berbading lurus dengan jumlah populasi sel $C$. vulgaris. Kisaran parameter kualitas air meliputi suhu 30,15 $32,24^{\circ} \mathrm{C}, \mathrm{pH} 8,4-9,0$, Salinitas 28,0 35,8 \%o. DO 5,15 - 6,06 ppm Kisaran kualitas air media kultur selama penelitian masih layak digunakan.
\end{abstract}

Kata Kunci : C. vulgaris, logam berat Timbal (Pb), populasi sel, Klorofil-a 


\section{PENDAHULUAN}

Gresik telah menjadi kawasan industri dari skala rumah tangga hingga skala multinasional. (Purnomo dkk, 2008). Industri-industri tersebut antara lain bergerak di bidang semen, industri pengolahan kayu, industri cat, industri tekstil, industri alat-alat rumah tangga, industri pupuk, industri peleburan baja dan pembangkit listrik. Selain itu di Gresik terdapat empat pelabuhan yang didarati kapal-kapal besar, yakni pelabuhan PT Semen Gresik, Pelindo III Gresik, PT Petrokimia Gresik dan PT Maspion. Dari aktivitas pelabuhan tersebut tentu akan dihasilkan limbah yang dibuang ke perairan sekitarnya (Purnomo dkk, 2008). Kontaminasi logam merupakan salah satu kontaminan yang ada dimana-mana, persisten, dan merupakan warisan masa lalu maupun yang akan datang, serta salah satu issue yang dapat menimbulkan penurunan kualitas lingkungan (Luoma dan Rainbow, 2008; Rahim, 2018; Rahim, 2018; Raim et al., 2016; Rahim et al., 2015).

Achyani dan Salin (2013) menyatakan, logam berat merupakan bahan pencemar yang paling banyak ditemukan di perairan akibat limbah Industri dan limbah perkotaan. Secara alamiah, unsur logam berat terdapat dalam perairan, namun dalam jumlah yang sangat rendah. Kadar ini akan meningkat bila limbah yang banyak mengandung unsur logam berat masuk ke dalam lingkungan perairan sehingga akan bersifat toxic. Logam berat dalam air mudah terserap dan tertimbun dalam fitoplankton yang merupakan titik awal dari rantai makanan, selanjutnya melalui rantai makanan sampai ke organisme lainnya (Fardiaz, 1992).

Berdasarkan latar belakang di atas maka tujuan penelitian ini adalah untuk menganalisis pengaruh, MTC dan perbedaan kandungan klorofil A pada populasi Chlorella sp. yang ditambahkan logam berat $\mathrm{Pb}$ dengan konsentrasi yang berbeda. Penelitian ini dalam skala laboratorium dilakukan agar kondisi lingkungan tidak menjadi faktor pembatas utama. Pemilihan Chlorella sp. sebagai objek penelitian adalah berdasarkan pertimbangan antara lain; Chlorella sp. telah digunakan secara luas terutama di panti-panti pembenihan ikan, udang, kerang-kerangan atau hewan budidaya lainnya. (Ukeles, 1971 dalam Meritasari dkk, 2012). C. vulgaris telah digunakan sebagai alternatif obat yakni sebagai antioksidan dan antinyeri selain memiliki efek hipoglikemik. Secara luas, C. vulgaris telah diproduksi dan dipasarkan sebagai suplemen makanan pada Negara Cina, Jepang, Eropa, dan Amerika (Mayasari, 2012) Chlorella sp. merupakan salah satu jenis green algae yang sangat diharapkan populasinya dalam lingkungan budidaya. 


\section{STUDI LITERATUR}

Chlorella sp. merupakan mikroalga yang termasuk dalam kelas alga hijau atau Chlorophycea. Mikroalga ini belum memiliki akar, batang, dan daun sejati, tetapi telah memiliki pigmen klorofil sehingga bersifat fotoautotrof (Kawaroe dkk, 2010). Klasifikasi Chlorella sp. (Bold \& Wynne 1985) adalah Filum: Chlorophyta, kelas: Chlorophyceae, ordo: Chlorococcales, famili: Oocystaceae, genus: Chlorella, spesies : Chlorella sp.

Chlorella sp. dapat tumbuh pada salinitas $25 \%$. Alga tumbuh lambat pada salinitas $15 \%$, dan hampir tidak tumbuh pada salinitas $0 \%$ dan $60 \%$. Chlorella sp. tumbuh baik pada suhu $20^{\circ} \mathrm{C}$, tetapi tumbuh lambat pada suhu $32^{\circ} \mathrm{C}$. Tumbuh sangat baik sekitar $20-23^{\circ} \mathrm{C}$ (Hirata, 1981 dalam Rostini, 2007).

Chlorella sp. bereproduksi secara aseksual dengan pembentukan autospora yang merupakan bentuk miniatur dari sel induk. Pemanfaatan Chlorella sp. dilakukan menggunakan teknik kultur. Kultivasi mikroalga dipengaruhi oleh beberapa faktor umum seperti factor eksternal (lingkungan) yang biasa dikenal. Faktor-faktor lingkungan yang berpengaruh terhadap laju pertumbuhan dan metabolisme dari makhluk hidup mikro tersebut terbagi atas atas faktor kimia antara lain ; Derajat Keasaman (pH), karbondioksida dan nutrien. Faktor fisika dipengaruhi oleh; salinitas, suhu, cahaya, dan aerasi

Logam berat $\mathrm{Pb}$ termasuk logam transisi yang dalam perairan ditemui dalam bentuk ion-ion bebas, pasangan ion organik, dan ion kompleks. Kedua logam ini belum diketahui manfaatnya bagi tubuh organisme, sebaliknya justru menimbulkan penyakit (Slamet, 1996).

\section{METODE}

Penelitian dan pengukuran kualitas air dilakukan pada bulan Oktober sampai November 2017. Kultivasi dilaksanakan di laboratorium Mandiri KaVe Dalegan. Analisis data menggunakan analisis statistik dan analisis pustaka. Analisis statistik dilakukan untuk mengetahui pengaruh pemberian logam berat $\mathrm{Pb}$ pada kultur mikroalga Chlorella sp. Analisis pustaka dilakukan untuk menjelaskan hasil penelitian berdasarkan analisis statistik dan tinjauan ilmiah lainnya. 
Analisis statistik yang dilakukan adalah Rancangan Acak Lengkap (RAL) dengan empat perlakuan dan tiga kali ulangan. Perlakuan dengan pemberian logam berat $\mathrm{Pb}$ pada kultur Chlorella sp. dengan konsentrasi 5 ppm, 10 ppm, 15 ppm dan 0.0 ppm sebagai kontrol.

Tahapan persiapan penelitian yang dilakukan antara lain sterilisasi alat dan media kultur, penyiapan air laut sebagai media klutur, pembuatan larutan stok timbal dan penyiapan bibit Chlorella sp. Parameter utama yang diamati selama penelitian adalah sebagai kelimpahan sel Chlorella sp. (sel/ml) setiap hari pada masing-masing tahap kultur penelitian utama selama total 10 hari kultur secara mikroskopis menggunakan haemocytometer. Parameter tambahan yang diamati meliputi temperatur ruangan perubahan temperatur ruangan dan kultur $\left({ }^{\circ} \mathrm{C}\right)$ secara manual, salinitas kultur (ppt), orthoposphat dengan metode spektrofotometri, dan $\mathrm{pH}$ kultur.

\section{HASIL DAN PEMBAHASAN}

Penentuan pola pertumbuhan pada sampling untuk menghitung jumlah sel menggunakan haemasitometer dan mikroskop. Nilai kepadatan sel yang didapat dari penghitungan matematis selanjutnya diturunkan dengan pendekatan logaritmik (log) kemudian diplotkan ke dalam suatu grafik berbentuk diagram batang. Pada hari ke-0 sampai dengan hari ke-2 tidak terjadi lonjakan pertumbuhan yang signifikan bahkan terjadi penurunan populasi hal ini diduga kerena sel Chlorella vulgaris yang dimasukan masih gagal beradaptasi yang disebabkan oleh perbedaan kondisi kualitas air pada media inokulan dengan lingkunagn yang baru, sehingga mengalami lysis sel. Hal ini didukung dengan pendapat dari Media dan kondisi lingkungan yang sama antara media inokulum dengan kultur menyebabkan $C$. vulgaris tidak perlu lagi melalui fase lag atau adaptasi untuk dapat Tumbuh (Sartika, 2010).

Tabel 1. Analisis varians populasi sel C. vulgaris dengan penambahan logam berat timbal $(\mathrm{Pb}) 5,10,15 \mathrm{ppm}$ pada hari ke-7

\begin{tabular}{lccccc}
\hline $\begin{array}{l}\text { Sumber } \\
\text { Ragam }\end{array}$ & DB & $\begin{array}{c}\text { Jumlah } \\
\text { Kuadrat }\end{array}$ & $\begin{array}{c}\text { Kuadrat } \\
\text { Tengah }\end{array}$ & $\begin{array}{c}\text { F } \\
\text { Hitung }\end{array}$ & Sig \\
\hline Perlakuan & 3 & $5,4 \times 10^{13}$ & $1,79 \times 10^{13}$ & 2,254 & 0,159 \\
\hline Galat & 8 & $6,4 \times 10^{14}$ & $7,95 \times 10^{13}$ & & \\
\hline Total & 11 & $1,2 \times 10^{14}$ & & \\
\hline Keterangan : angka signifikan lebih besar dari $0,2 .(\mathrm{P}<0,2)$ signifikan \\
\hline
\end{tabular}


Hasil pembacaan pada tabel 1 menunjukkan perbedaan dengan tabel analisis sidik ragam sebelumnya yang telah disajikan, dengan $\mathrm{F}$ hitung sebesar 2,254 dan F tabel $(\mathrm{P}<0,2)$ sebesar 0,159 hal ini berarti tingkat kepercayaan berada pada kisaran yang ditentukan yaitu sebesar $85,9 \%$, dimana angka signifikan $>20 \%$. Pada analisis sidik ragam $\mathrm{H}-7$ penambahan logam berat timbal $(\mathrm{Pb})$ berpengaruh nyata pada populasi sel Chorella vulgaris yang di kultur dalam skala laboratorium. Jika dilakukan analisis regresi linier, keberpengaruhan penambahan logam berat timbal $(\mathrm{Pb})$ sebesar 38,65\%, pada prosentase tersebut sudah cukup mempengaruhi populasi sel yang dikultur.

\begin{tabular}{llcccc}
\hline Tabel 2. & \multicolumn{5}{c}{ Analisis varians populasi sel C. vulgaris dengan penambahan } \\
& \multicolumn{1}{l}{ logam berat timbal $(\mathrm{Pb}) 5,10,15$ ppm pada hari ke-13 } & \\
\hline $\begin{array}{c}\text { Sumber } \\
\text { Ragam }\end{array}$ & DB & $\begin{array}{c}\text { Jumlah } \\
\text { Kuadrat }\end{array}$ & $\begin{array}{c}\text { Kuadrat } \\
\text { Tengah }\end{array}$ & F Hitung & Sig \\
\hline Perlakuan & 3 & $4,3 \times 10^{12}$ & $1,42 \times 10^{12}$ & 1,463 & 0,196 \\
\hline Galat & 8 & $7,8 \times 10^{12}$ & $9,76 \times 10^{11}$ & & \\
\hline Total & 11 & $1,2 \times 10^{13}$ & & & \\
\hline
\end{tabular}

Keterangan : angka signifikan lebih besar dari 0,2. $(\mathrm{P}<0,2)$ signifikan

Analisis varians juga dilakukan pada hari ke-13, hal ini dikarenakan pada hari ke-13 merupakan fase death yang dialami oleh sebagian besar sel $C$. vulgaris yang dikultur pada penelitan yang dilakukan. Pada analisis ini dapat disimpulkan bahwa fase death yang dialami dapat dimungkinkan karena pengaruh penambahan logam berat timbal $(\mathrm{Pb})$ hal tersebut didukung dengan angka $\mathrm{F}$ tabel $<20 \%$ yaitu 0,196 , sedangkan $\mathrm{F}$ hitung yang didapat menunjukkan angka 1,463, jadi dikatakan bahwa H1 diterima.

Penambahan logam berat timbal $(\mathrm{Pb})$ secara keseluruhan dapat menghambat pertumbuhan populasi sel $C$. vulgaris, hambatan pertumbuhan yang dibuktikan dengan Analysis of variance terlihat perbedaan populasi sel $C$. vulgaris dimulai pada $\mathrm{H} 7$ kultivasi. Hal ini diduga karena sel mengasorpsi kandungan logam berat timbal $(\mathrm{Pb})$ dalam media kultivasi. Jumlah toksikan yang masuk kedalam sel sangat banyak sehingga tidak dapat dinetralkan oleh sel tersebut, sehingga mempengaruhi percepatan kerusakan sel $C$. vulgaris yang dikultivasi kemudian menganggu proses pembelahan sel yang dilakukannya. 
Data penelitian yang dianalisis menggunakan ANOVA dan mendapatkan $\mathrm{F}$ hitung <20\% maka dilanjutkan dengan uji BNT (Beda Nyata Terkecil). Data yang dianalisis menggunakan BNT adalah data pada $\mathrm{H} 7$ dan $\mathrm{H}$ 13. Hal ini dikarenkan pada H 7 menunjukkan pertumbuhan yang optimum, dan pada $\mathrm{H} 13$ menunjukkan dimana populasi $C$. vulgaris yang dikultur mengalami fase kematian (death).

\begin{tabular}{ccc}
\hline \multirow{2}{*}{ Tabel 3. } & \multicolumn{2}{l}{$\begin{array}{l}\text { Hasil uji lanjut BNT 0,2 (Beda Nyata Terkecil) populasi } C . \\
\text { vulgaris pada H 7 dan H 13. }\end{array}$} \\
\cline { 2 - 3 } Perlakuan & \multicolumn{2}{c}{ Rata-rata } \\
\cline { 2 - 3 } & $\mathrm{H} \mathrm{7}$ & $\mathrm{H} 13$ \\
\hline $\mathrm{A}$ & $2,37 \times 10^{6 a}$ & $1,13 \times 10^{5 a}$ \\
\hline $\mathrm{B}$ & $2,98 \times 10^{6} \boldsymbol{b}$ & $4,67 \times 10^{5} \boldsymbol{a}$ \\
\hline $\mathrm{C}$ & $6,67 \times 10^{6} \boldsymbol{c}$ \\
\hline $\mathrm{D}$ & $7,77 \times 10^{6} \boldsymbol{d}$ & $1,59 \times 10^{6} \boldsymbol{c}$ \\
\hline Keterangan & : nilai yang dikuti huruf yang sama menandakan tidak berbeda nyata
\end{tabular}

Tabel 3. dapat dijelaskan bahwa pada H 7 mendapatkan hasil yang berbeda nyata pada semua pelakuan, hal ini disebabkan sel C. vulgaris, sehingga hasil uji BNT pada $\mathrm{H} 7$ semua perlakuan menujukkan hasil yang berbeda nyata.. hal ini dikarenakan dinding sel tidak mampu menahan paparan logam berat $\mathrm{Pb}$ yang diberikan, sehingga tiak mampu melindungi inti sel maupun organ dalam sel yang lain. Safi dkk (2014), menyatakan pada dasarnya sel mampu melindungi dirinya dari lingkungan yang keras bervariasi sesuai dengan fase pertumbuhan yang dialami. Pada fase awal dinding sel yang baru terbentuk tetap rapuh, dengan lapisan unilaminar padat dengan lapisan elektron setebal $2 \mathrm{~nm}$. Dinding sel individu yang baru secara bertahap meningkat ketebalannya hingga mencapai $17-21 \mathrm{~nm}$ setelah memasuki fase pematangan. Dimana mikro fibrilar lapisan terbentuk seperti lapisan mirip chitosan yang tersusun atas glukosamine yang mempengaruhi kinerjanya. ketebalan dan komposisi dinding sel tidak konstan karena sel dapat berubah sesuai pertumbuhan dan lingkungan yang berbeda sehingga lapisan trilaminar luar dapat pecah karena residu yang resisten. 
Kisaran suhu yang digunakan pada penelitian ini suhu media kultur berkisar $30,15^{\circ} \mathrm{C}$ hingga $32,24^{\circ} \mathrm{C}$. Suhu tersebut tergolong tinggi jika dibandingkan dengan pernyataan Putra (2013) bahwa, suhu optimal bagi fitoplankton untuk dapat tetap tumbuh selama proses kultivasi ialah antara $20^{\circ} \mathrm{C}-24^{\circ} \mathrm{C}$. Data kualitas air parameter $\mathrm{pH}$ selama penelitian masih dalam kondisi optimal berkisar antara 8,4 - 9,0. Perlakuan A pada hari ke- 1 terus mengalami penurunan hingga hari ke-10. Hal ini seiring dengan laju pertumbuhan populasi sel $C$. vulgaris. Kenaikan populasi sel $C$. vulgaris berbanding lurus dengan proses fotosintesis yang mengakibatkan kenaikan $\mathrm{pH}$, dimana semakin tinggi jumlah sel semakin besar pula proses fotosintesis yang terjadi dan berimbas dengan kenaikan $\mathrm{pH}$ media.

Salinitas yang diamati selama kultivasi berkisar antara 28,0 dan 35,8 \%o. Salinitas air media kultivasi relatif meningkat setiap harinya. Pada $\mathrm{H}-0$ hingga $\mathrm{H}-3$ nilai salinitas tidak terjadi perubahan yang signifikan, memasuki $\mathrm{H}-4$ hingga $\mathrm{H}-10$ fluktuasi salinitas terus mengalami peningkatan. Dugaan terjadinya evaporasi pada media kultivasi akibat adukan aerasi menyebabkan kenaikan salinitas yang begitu jauh jika dibandingkan dengan hari sebelumnya. Pada hasil pengamatan dapat diketahui kandungan oksigen terlarut berkisar 5,15 hingga 6,06 ppm. Pada penelitian ini kandungan $\mathrm{PO}_{4}$ yang dianalisa pada $\mathrm{H} 0$ sebesar $1,5 \mathrm{ppm}$, hal ini disebabkan pada $\mathrm{H} 0$ sudah dilakukan penambahan nutrien buatan berupa walne, dimana walne sudah mengandung $\mathrm{PO}_{4}$ sehingga menambah konsentrasi $\mathrm{PO}_{4}$ alami yang terdapat pada air sumber yang digunakan.

Kandungan yang paling dominan dimiliki oleh fitoplankton adalah klorofil-a. Oleh karena itu klorofil-a dapat dijadikan sebagai salah satu indikator kesuburan perairan (Zakaria, 2013). Analisa kandungan klorofil-a dilakukan pada hari ke-11, hal ini dilakukan dengan pertimbangan kondisi media kultur belum mengalami fase death total, sehingga sel-sel C. vulgaris dalam kondisi masih baik. Pengukuran nilai klorofil-a yang dinyatakan dalam $\mu \mathrm{gr} / \mathrm{L}$ dilakukan menggunakan metode spektrofotometri mendapatkan nilai pada perlakuan A, B, C dan D berturut-turut adalah 129,87 $\mu \mathrm{gr} / \mathrm{L}$, $16,65 \mu \mathrm{gr} / \mathrm{L}, 110,30 \mu \mathrm{gr} / \mathrm{L}$ dan $147,35 \mu \mathrm{gr} / \mathrm{L}$. 
Ditilik dari besaran kandungan klorofil-a yang telah dianalisa, didapatkan korelasi nyata dengan jumlah kepadatan sel C. vulgaris, dimana kontrol didapatkan kandungan klorofil-a tertinggi dibanding dengan perlakuan lainnya karena populasi kontrol lebih tinggi dibandingkan dengan perlakuan lainnya. Kandungan klorofil-a terendah terdapat pada perlakuan $\mathrm{B}$, karena pada hari dimana pengambilan sampel dilakukan, perlakuan B dengan populasi terrendah. Pada penelitian ini didapatkan hasil jumlah populasi berbanding lurus dengan kandungan klorofil-a yang didapatkan.

\section{KESIMPULAN DAN SARAN}

Pada H 13 beda nyata ditunjukkan pada perlakuan C (15 ppm) dan D (Kontrol) dimungkinkan sel $C$. vulgaris tidak mampu bertahan hidup lebih lama karena energi pada sel telah habis untuk mempertahankan diri dari paparan logam berat timbal $\left(\mathrm{PbNO}_{3}\right)$ yang dipaparkan. Sedangkan pada perlakuan D (Kontrol), jumlah sel lebih banyak dibandingkan dengan perlakuan lain yang berbanding terbalik dengan perlakuan yang lain. Hasil analisa klorofil-a berbading lurus dengan jumlah populasi sel $C$. vulgaris dimana pelakuan A didapatkan 129,87 $\mu \mathrm{gr} / \mathrm{L}, \mathrm{B}, 16,65 \mu \mathrm{gr} / \mathrm{L} \mathrm{C}, 110,30 \mu \mathrm{gr} / \mathrm{L}$ dan $\mathrm{D}, 147,35 \mu \mathrm{gr} / \mathrm{L}$. Hasil penelitian memerlukan uji serapan logam berat timbal $(\mathrm{Pb})$ pada sel C.vulgaris yang dikultur sehingga dapat diketahui persentase kemampuan sel dalam menyerap kontaminan yang ditambahkan. Selain itu perlu dilakukan analisis konsentrasi logam berat timbal $(\mathrm{Pb})$ pada media pasca kultur.

\section{DAFTAR PUSTAKA}

Fardiaz, S. 1992. Polusi Air dan Udara. Yogyakarta: Kanisius.

Kawaroe, M., T. Partono, dkk., (2010). Mikroalga : Produksi dan pemanfaatannya Untuk Bio Bahan bakar. Bogor, IPB Press.

Luoma, S.N. and P.S. Rainbow. 2008. Metal contamination in aquatic environment: science and lateral management. Cambridge Univer-sity Press. Cambridge. 556

Meritasari, D., Mubarok, A. S., Sulmartiwi, L., \& Masithah, E. D. 2012. Pengaruh pemberian pupuk cair limbah ikan lemuru (sardinella sp.) dengan dosis yang berbeda terhadap pertumbuhan chlorella sp. Jurnal Ilmiah Perikanan dan Kelautan, 4(1).

Purnomo, T., \& Muchyiddin, M. 2008. Analisis Kandungan Timbal (Pb) pada Ikan Bandeng (Chanos chanos Forsk.) di Tambak Kecamatan Gresik. Neptunus, 14 (1). 
Putra, H. A. (2013). Laju Pertumbuhan Spesifik, Bobot Biomassa, dan Doubling Time Mikroalga (Nannochloropsis sp.) pada Fotobioreaktor dan Open Raceway Pond Skala Pilot Plant.

Rahim, A. R., Herawati, E. Y., Nursyam, H., Hariati, A. M. 2015. Cells Characteristics, Growth, and Quality of Gracilaria verrucosa Seaweed Production with Different Doses of Vermicompost Fertilizer. International Journal of Science Technology and Engineering, Volume 2, Issue 1.

Rahim, A. R., Herawati, E. Y., Nursyam, H., Hariati, A. M. 2016. Combination of Vermicompost Fertilizer, Carbon, Nitrogen and Phosphorus on Cell Characteristics, Growth and Quality of Agar Seaweed Gracilaria verrucosa. Nature Environment \& Pollution Technology, 15(4).

Rahim, A. R. 2018. Application of Seaweed Gracilaria verrucosa Tissue Culture using Different Doses of Vermicompost Fertilizer. Nature Environment and Pollution Technology, 17(2), 661-665.

Rahim, A. R. 2018. Utilization of Organic Wastes for Vermicomposting Using Lumbricus rubellus in Increasing Quality and Quantity of Seaweed Gracilaria verrucosa. Asian Journal of Microbiology, Biotechnology and Environmental Sciences. Volume 20, No. 2: 2018: S17 - S23.

Rostini, I. 2007. Karya Ilmiah. Kultur Fitoplankton (Chlorella sp. dan Tetraselmis sp.) pada Skala Laboratorium di Instalasi Penelitian dan Pengkajian Teknologi Pertanian Bojonegara. Fakultas Perikanan dan Ilmu Kelautan. Universitas Padjajaran. Bandung.

Safi,C., Zebib, B., Merah, O., Pontalier, P., Garcia,C.V. 2014 Morphology, Composition, Production, Processing and Applications of Chlorella vulgaris: A Review

Sartika, D. 2010. Aktivitas Antioksidan Lipid Mengandung Pigmen dan Komposisi Kimia Dari C. vulgaris Pada Umur Panen yang Berbeda. Departemen Teknologi Hasil Perairan Fakultas Perikanan Dan Ilmu Kelautan Institut Pertanian Bogor. Bogor.

Slamet, J.S. 1996. Kesehatan Lingkungan. Gadjah Mada University Press. Yogyakarta. Zakaria, I J. Komposisi dan Kandungan Klorofil-a Fitoplankton Pada Musim Timur Dan Barat di Estuari Sungai Peniti, Kalimantan Barat. Universitas Andalas. 